\title{
A memória como patrimônio ou a História como prática social? Reflexões sobre práticas de memória e ensino de história na Pedagogia do Movimento Sem Terra
}

The memory as heritage or history as a social practice? Reflections about practices of memory and history education in Pedagogy of the Landless Movement

Marizete Lucini*

\section{Resumo}

$\mathrm{O}$ artigo discute a memória produzida na prática social como patrimônio de homens e mulheres na luta pela terra. A reflexão que propomos funda-se na fenomenologia da Memória proposta por Paul Ricoeur, evidenciando-se que a História como uma prática social desenvolvida em um Assentamento de Reforma Agrária atua na produção de uma Memória que ao ser apropriada por esse grupo constitui seu patrimônio material e imaterial. Palavras-chave: Memória; História; Movimento dos Trabalhadores Sem Terra-MST.
Abstract

The paper discuss the produced memory in social practice with men and women's heritage in the struggle for land. The reflection that we propose is based in phenomenology of memory proposed by Paul Ricoeur, evidencing the History as a social practice developed in one agrarian reform settlement that acts in production of Memory that being appropriated by this group constitute their material and immaterial heritage.

Keywords: Memory; History; The Landless Movement (Brazil) - MST.

Em seu uso forte, a memória se torna um instrumento político, seja para submeter e levar à conformidade, seja para alimentar as resistências, seja para acompanhar a irrupção da liberdade e, depois, as lutas que nascem da transição para outras formas de sociedade.

Georges Balandier

Ao refletirmos sobre a memória como instrumento de resistência por um determinado grupo social, nos parece pertinente refletir sobre como esse grupo trabalha com a memória, no sentido de produzi-la e transformá-la em patrimônio constantemente atualizado através de sua prática social.

* Doutora em Educação, Professora da Universidade Federal de Sergipe (UFS). malucini@hotmail.com 
Neste texto propomos apresentar a memória produzida na prática social como patrimônio de homens, mulheres e crianças na luta pela terra, evidenciando como ela é construída, apropriada como a História do grupo, constituindo seu patrimônio imaterial sob a materialidade do espaço vivido.

As reflexões aqui apresentadas resultam de um trabalho de pesquisa em que, inicialmente, o nosso interesse se voltava para o Ensino de História nos anos iniciais em uma Escola situada em um Assentamento de Reforma Agrária do MST, cuja proposta pedagógica estivesse vinculada à Pedagogia do Movimento Sem Terra. Contudo, ao realizar a pesquisa de campo, deparamos com processos identitários em permanente conversação com um passado feito patrimônio na prática social desse grupo.

Ao acompanharmos as aulas desenvolvidas em sala de aula e ao observarmos os cadernos das crianças, pudemos comprovar que o Ensino de História centrava-se em torno das datas comemorativas, com um privilégio às datas significativas para os trabalhadores, segundo a visão daquele grupo social. Contudo, o ensino de história desenvolvido na escola do assentamento difere em alguns pontos do conteúdo desenvolvido em escolas regulares de outros sistemas de ensino.

Destacamos o caráter político, em coerência com a proposta pedagógica do MST, já que as datas e os conteúdos desenvolvidos são ministrados com o objetivo de possibilitar a inserção dos excluídos das narrativas históricas, mediante a opção de trabalhar a história dos trabalhadores e de personagens históricos que são identificados como significativos para o Movimento.

Outro destaque que necessita ser evidenciado e está diretamente ligado à reflexão que aqui realizamos refere-se ao Ensino de História com base nas práticas de memória. Essas práticas constituem-se também em comemorações e celebrações pertinentes a alguns personagens ou acontecimentos significativos para esse grupo social que se desenvolvem no âmbito do Assentamento. Práticas que se efetivam como resistência a uma memória produzida pela História que não contempla os trabalhadores do Campo.

Assim, uma memória de resistência dos povos do campo é produzida como forma de enfrentamento nas celebrações e comemorações onde são lembradas as ligas camponesas, Zumbi e a resistência negra, os Sem Terra que tombaram na luta, os indígenas desterritorializados, Chico Mendes, Che Guevara e tantos outros. Como afirma Balandier (1999, p.43), "a luta política 
é também memória contra memória". Trata-se da produção de uma memória poderosa ${ }^{1}$ que é atualizada a cada celebração, a cada comemoração e a cada narrativa empreendida pelos sujeitos que compõem o grupo e, ao narrar, dizem de si, de quem são, de suas origens, de suas lutas e de suas conquistas. Justificam o presente e projetam um futuro a partir das memórias com que estabelecem processos de identificação.

A presença de uma memória poderosa que emerge nas narrativas, nas imagens e nas denominações dos espaços nos remeteu ao labirinto construído por Dédalo para aprisionar o Minotauro. Foi necessário, portanto, emprestar o fio de Ariadne para encontrar a saída do labirinto.

Assim, ao compreendermos o labirinto como o campo complexo que adentraríamos, nos propusemos a compreender como a memória de um grupo composto por sujeitos diversos se constitui e se torna a memória do grupo. ${ }^{2}$ Uma primeira aproximação nos evidenciou que a memória se constituía como prática social. Por prática social entendemos todas as ações desenvolvidas no âmbito da cultura, da produção, da educação, das relações sociais entre os membros do grupo e também com sujeitos de outros grupos sociais.

Assim, na efetivação da vida em sociedade, a memória e, também, a história sempre estavam presentes como instrumento político que ancorava as ações do grupo no presente.

No entanto, se observamos que a memória se efetivava como prática social e, por isso, constituía-se em um instrumento político poderoso, nos faltava compreender o seu funcionamento em si, percebê-la, senti-la nos labirintos construídos por Dédalo.

Para tanto, é necessário circunscrevê-la, o que nos impele a realizarmos um percurso em que a abordagem fenomenológica está incluída, acreditando que isso permitirá nos aproximarmos do que é a memória, e daquilo de que temos memória. Possivelmente não atinjamos uma resposta sem os aportes exteriores, o que nos permite, então, compreender que a memória não existe sem esses aportes materiais, e também que os aportes materiais de nada valeriam, se não tivéssemos do que lembrar e por que lembrar.

Os dados coletados no campo nos possibilitaram compreender o "trabalho de enquadramento da memória” (Pollak, 1992), expresso em rituais e práticas cotidianas, no ensinado na escola, na publicação e divulgação de materiais que narram sua trajetória, na participação em comemorações de eventos 
significativos para o grupo, vividos por eles ou não. Mas que são sempre narrados como parte de sua memória.

A produção de uma memória supõe que outra foi silenciada, ou apenas não evidenciada. Assim, a memória pode significar a resistência, "aquela que se opõe ao esquecimento e arma a vigilância dessas imagens horríveis, insuportáveis, recebidas do passado" (Balandier, 1999, p.41).

A memória poderosa que funda as sociedades e nelas age se organiza a partir de acordos com as formas institucionais localizadas, pacificando arquivo e patrimônio, fixando-se em "mitos e símbolos selecionados a serviço do regime estabelecido" (Balandier, 1999, p.45).

Centrada na oralidade, a memória das sociedades sem escrita cumpre o papel de transmitir conhecimentos considerados secretos e a vontade de manter uma memória mais criadora que repetitiva. Logo, a transmissão da memória através da oralidade distancia-se da interpretação de que se trata de uma "transmissão palavra por palavra". Comporta a ideia da transmissão geradora de sentido. Ou seja, uma transmissão que mantém sua essência, mas que recria o conhecimento na narração. Narração que a atualiza, resultando, no entendimento de Balandier (1999, p.42), "de circunstâncias e exigências expressas sob o efeito do acontecimento, das interpretações que a colocam sob um novo enfoque e das condições culturais e técnicas sobre sua presença. É tanto um revelador do tempo de sua emergência, quanto um testemunho recebido do passado".

A narrativa oral é constituinte da memória, não apenas das sociedades sem escrita, embora por elas fosse e seja inaugurada. Mesmo nas sociedades contemporâneas que se utilizam da escrita, a oralidade é uma prática que possibilita aos sujeitos atribuírem um sentido para o passado, um significado que é transmitido pela narrativa e produz um saber. Como diz Certeau: "Este saber se faz de muitos momentos e de muitas coisas heterogêneas" (Certeau, 1994, p.157-158).

A transmissão oral, como bem alerta Connerton (1999), atribui um sentido, um significado para o narrado, uma característica de veracidade revivida por quem narra e acompanhada por quem ouve. Assim, ao ouvir a narração comum nas comemorações e celebrações, o narrado é fixado e constitui a memória individual e coletiva. 
À memória pensada a partir das fixações possibilitadas pelas comemorações e celebrações, Balandier nos indica que, nessas ocasiões, a memória poderosa "mantém a adesão apaixonada pelos acontecimentos fundadores, dá um valor exemplar às figuras celebradas” (1999, p.45). Celebrações e comemorações que, com o aparecimento da escrita, são intensificadas na demarcação de um calendário e de um registro que se torna documento.

Um saber é organizado pelo grupo ao rememorar e apresentar a memória às novas gerações, constituindo-se, assim, em uma organização de um novo poder, o de selecionar o que deve ser lembrado e comemorado. Na afirmação de que a memória se torna um novo poder, está presente o caráter seletivo da memória, em basicamente dois sentidos.

$\mathrm{O}$ primeiro refere-se ao que pode e deve ser transmitido. Encontramos, nessa abordagem, a análise de que há uma memória oficial que é produzida como uma memória pública, cujos mecanismos de produção situam-se na elaboração de uma história oficial, amparada em um calendário que a legitima em suas comemorações, cunhando uma identidade social pela cronologia política e registrada pela escrita, mas também pelas comemorações. ${ }^{3}$ Nessa perspectiva, os conflitos entre diferentes memórias remetem-nos a considerar que o tecido social é composto por diferentes grupos e interesses sociais, e que os conflitos não são determinantes de uma possível sobreposição da memória oficial à memória subterrânea, mas que, "a rigor, pode-se dizer que, além da transferência entre datas oficiais, há também o predomínio da memória sobre determinada cronologia política, ainda que esta última esteja mais fortemente investida pela retórica, até mesmo pela reconstrução historiográfica" (Pollak, 1992, p.4).

Essa transmissão geradora de sentido é, portanto, constituinte de identidades, não sem conflitos e disputas, mas uma forma em que "somos afetados pelo passado" naquilo que o interrogamos.

Ninguém pode construir uma autoimagem isenta de mudança, de negociação, de transformação em função dos outros. A construção da identidade é um fenômeno que se reproduz em referência aos outros, em referência aos critérios de aceitabilidade, de admissibilidade, de credibilidade, e que se faz por meio da negociação direta com os outros. Vale dizer que memória e identidade podem perfeitamente ser negociadas, e não são fenômenos que devam ser compreendidos como essências de uma pessoa ou de um grupo. (Pollak, 1992, p.5) 
O segundo sentido diz respeito ao caráter seletivo da memória em si, pois a memória de um grupo ou a memória individual trabalha na produção de coerências de unidades, na continuidade e na atualização, na construção de respostas às perguntas do momento. É o trabalho da memória em si (Pollak, 1992) como um investimento, pois após a constituição da memória, ela realiza por si um trabalho que resultará em um investimento no passado que rende juros. Geralmente esse trabalho da memória em si ocorre em função da percepção dos outros, em que é preciso uma rearrumação da memória do próprio grupo, pois demanda investimentos na identidade do grupo, se esta não estiver suficientemente sedimentada.

Para compreendermos a memória em si, nos alicerçamos na fenomenologia da memória discutida por Paul Ricoeur. Contudo, para pensarmos no sentido de um esboço fenomenológico da memória como propõe Ricoeur (2003), apresentaremos alguns excertos da narrativa de lembranças de um assentado na festa do $17^{\circ}$ aniversário do assentamento, num espaço denominado pelos locutores de "Depoimentos de sobrevivência". Tomemos esse depoimento como coisas que aconteceram, dessa e não de outra maneira, e, posteriormente, realizaremos uma releitura fenomenológica, identificando os elementos discutidos por Ricoeur.

Bom dia companheiros e companheiras! Me incumbiram, me deram uma tarefa de falar ... a Elisa falou que em 2 minutos, né? Falar sobre as dificuldades do acampamento. Na verdade achei impossível de falar em 2 minutos, mas agora tô com dificuldade de falar das dificuldades (voz trêmula, com respiração nervosa). Isso porque na cabeça dos companheiros e na minha cabeça passa um filme de muitos momentos que passamos juntos e que a gente com união e organização superou. Eu vou tentar falar das mais marcantes, com certeza teria um monte de gente que podia falar bem das dificuldades. Eu lembro... quando nós tava acampado em Abelardo Luz, que era lá nas macieiras, inclusive eu tô vendo o seu Armindo, o seu Ademar, que uma noite deu muito frio, na verdade lá é frio, fica perto dos campos de Palmas, então fez, durante a noite nevou muito, então naquela noite nós passamos a noite nós passamos a noite toda puxando a neve de cima dos barracos com enxada ... Então naquele momento foi bastante difícil, nós os dirigentes, as lideranças passaram muitas dificuldades, perseguição (a narrativa aqui é intercalada pela emoção) inclusive ... teve companheiro que... teve companheiro que... teria que... pra dormir no seu barraco tinha que fazer guarita... 
Outros companheiros tinham que cuidar, que vigiar, porque corriam riscos de vida ... e foi lá em Itaiópolis que foi possível a gente discutir a proposta do trabalho coletivo e que hoje nós estamos aqui. Inclusive lembrando, eu lembro que para fazer a lista, para definir as pessoas que estão aqui sentadas hoje, nós fazíamos reuniões no mato, nós fazíamos reuniões de noite. Os companheiros que tão até lembram, nós fazia reunião de noite, no mato porque a situação tava bastante difícil, então não podia vazar e ninguém podia saber quem vinha para cá. Felizmente a gente conseguiu. Chegando aqui, também no acampamento nós tivemos inúmeras dificuldades, precisaria muito tempo para falar. Mas uma das piores dificuldades se chama preconceito. O preconceito é a pior dificuldade. É a pior dificuldade porque no tempo de acampamento nós não era visto como cidadão comum, cidadão normal, nós era visto como baderneiro, como vagabundo, como pessoas desocupadas. E prova disso, quando nós cheguemo aqui, aqui em Dionísio, a primeira vez, isso fazia uns 15 dias que nós tava aqui, aí resolvemo conhecê o terreno, dá uma olhada por roda como é que era, né? Fumo na São Francisco e aí se reunimo uns grupo de rapaz, uns 15,16 ...é brincadeira, mas se eu dissé pra vocês que nós fomos recebidos a bala. Nós chegamos lá, tinha mais que 20 soldados e receberam nós a bala. Inclusive eu vi o Seu Rodrigues, tá ali né?, Seu Rodrigues que é de São Francisco, que é testemunha disso. ... Então muito obrigado e uma boa festa a todos. (Ilário, Assentado em depoimento no $17^{\circ}$ aniversário do Assentamento)

Do depoimento de Ilário, muitos são os elementos presentes, e optamos por alguns excertos. Ao indicarmos que o tomamos como algo que aconteceu dessa e não de outra forma, temos como pressuposto que o que foi narrado, foi feito por quem o viveu, num pronunciamento público, diante de outras pessoas que também viveram esses momentos, e esteve carregado de emoções, nas reticências, nas lágrimas, na ênfase das palavras e, principalmente, no apoio buscado entre aqueles que foram suas testemunhas.

Ricoeur (2003) propõe uma espécie de tipologia regulada para compreender como podemos reconhecer essas coisas como do passado, desejando desviar da polissemia própria das lembranças, organizadas em pares oposicionais. O primeiro é o binômio do hábito e da memória. O filósofo toma-os como parte de uma série contínua de fenômenos mnemônicos (Ricoeur, 2003, p.44). Propõe, primeiro, que afastemos a ideia de oposição entre memória-hábito e memória-lembrança, pois, para Ricoeur, o que coloca os dois termos em uma comunidade é a relação com o tempo. Ambos os casos pressupõem uma 
relação com a anterioridade, e a diferença reside no fato de que o hábito está incorporado no presente, não marcado e não declarado como passado.

O esboço fenomenológico pretendido pelo filósofo encontra no binômio hábito/memória a possibilidade de aplicar ao problema da memória um distanciamento temporal. Para Ricoeur:

La operación descriptiva consiste entonces en clasificar las experiencias relativas a la profundidad temporal desde aquellas en las que el pasado se adhiere, de alguna forma, al presente, hasta aquellas en las que el pasado es reconocido en su dimensión pasada del pasado. (Ricoeur, 2003, p.45)

Ricoeur define com Bergson a memória-hábito como "aquella que desplegamos cuando recitamos la lección sin evocar, una por una, las lecturas sucesivas del período de aprendizaje" (Ricoeur, 2003, p.45). Portanto, a memória-hábito é a que utilizamos no presente, a memória que atua e é usada para ler e escrever, não necessitando recorrer às etapas de aprendizagens que tivemos para construí-la toda vez que a formos utilizar. A memória-lembrança é de outro tipo, é aquela em que uma imagem nos vem à mente e será sempre essa imagem, não podendo ser modificada. É espontânea, não se repete, exige que nos abstraiamos da ação presente (Ricoeur, 2003, p.45-46).

Assim, com a memória-hábito, identificamos a linguagem utilizada por Ilário. A expressão "companheiros e companheiras" é parte de sua forma de narrar. Certamente, a leitura, a escrita, o andar, o movimentar-se, tudo isso identificamos como memória-hábito. A memória-lembrança é a matéria com que ele elabora a sua narrativa, e em suas expressões isso fica claro quando, ao justificar a dificuldade em selecionar o que falar, anuncia: "na cabeça dos companheiros e na minha cabeça passa um filme de muitos momentos que passamos juntos".

O segundo binômio apontado por Ricoeur refere-se à evocação e busca. Entende por evocação o advento atual de uma lembrança. Ou seja, lembramos disto ou daquilo em tal ou qual ocasião. Assim, entende a evocação como uma afecção por oposição à busca. Argumenta, em seguida, que, para Platão, a busca significa reaprender o que se esqueceu e, para Aristóteles, é a rememoração, em que há uma anterioridade da coisa advinda ao que se dirige sua evocação presente. Ao colocar em primeiro plano a anterioridade da coisa 
advinda, considera a dimensão cognitiva da memória com um caráter de saber, o que possibilita que ela seja confiável ou não.

Outro polo do binômio da evocação e busca que é abordado refere-se à anamnese, que Platão entendia como o saber pré-natal, do qual seríamos separados pelo nascimento, em que a vida seria um eterno reaprender. Aristóteles a tomará como rememoração, e Ricoeur a denominará de busca: "El esfuerzo de rememoración puede tener éxito o fracasar. La rememoración lograda es una de las figuras de lo que llamamos la memoria 'feliz"' (Ricoeur, 2003, p.48).

O esforço em lembrar está presente na afirmação de que "inclusive lembrando, eu lembro que para fazer a lista, para definir as pessoas que estão aqui sentadas hoje, nós fazíamos reuniões no mato, nós fazíamos reuniões de noite". Ao ser chamado para realizar esse depoimento, o que foi feito com antecedência pelos organizadores da festa, Ilário fez o exercício de lembrar, por isso, lembrando, ele lembra, seleciona e organiza sua narrativa. Isso não significa que a evocação é falsa? Não. Ele se lembra do que o afetou. É a rememoração trabalhosa, pois que pela busca organiza e narra. Como rememoração instantânea, evoca lembranças que surgem de outras lembranças diante dos seus ouvintes no ato de narrar.

Ricoeur (2003) cita o exemplo que Bergson apresenta, em que duas posturas podem nos ocorrer ao ouvirmos um discurso. Trata-se de que, ao rememorar fatos passados e ao interpretar fatos presentes, podemos ficar tensos ou relaxados. A pergunta que Bergson faz é se em ambos os casos o jogo de representações é o mesmo. Se são da mesma espécie os elementos intelectuais, e se entre eles se mantêm as mesmas relações.

La evocación voluntaria de un recuerdo consiste precisamente en esta travesía de los planos de conciencia. Se propone, pues, un modelo para separar la parte de automatismo, de rememoración mecánica, y la da reflexión, de reconstitución inteligente, íntimamente mezcladas en la experiencia ordinaria. (Ricoeur, 2003, p.49)

A experiência sugerida possibilita dois tipos de leitura, cuja diferenciação ocorre no momento da aprendizagem, pois naquela em que nos é exigida uma reflexão, haveremos de retroceder a uma espécie de esquema, em que ligações precisam ser estabelecidas entre diferentes ideias, possivelmente partindo do que Bergson nomeia como "esquema dinâmico". Este consiste na representação que não contém tanto as imagens mesmas como a indicação do que temos 
de fazer para reconstruí-las. Esse "esquema dinâmico" atuaria como guia, que indica a direção do esforço que fazemos (p.49-50). A outra leitura situar-se-ia no âmbito da rememoração mecânica, na qual não há a necessidade de esforço intelectual para estabelecer as ligações entre o que ouvimos e os passos das aprendizagens anteriores, apenas compreendemos sem um esforço de memória: "Diremos, pues, que 'el esfuerzo de rememoración consiste en convertir una representación esquemática, cuyos elementos se interpenetran, en una representación llena de imágenes, cuyas partes se yuxtaponen”" (Ricoeur, 2003, p.50).

O esforço intelectual se dá no presente, mas se dirige ao passado, no caso da leitura analítica, e, também, no caso da leitura mecânica. Porém, neste último parece-nos não haver um trabalho de intelecção:

lo que hace del trabajo de memoria, de intelección, un esfuerzo, a saber, la dificultad que tiene por señal una molestia o un obstáculo, en fin, el aspecto propiamente temporal de ralentización exigida, tanto del esquema dinámico como de las imágenes mismas en las que el esquema intenta escribirse. Es el hábito el que resiste a la invención. (Ricoeur, 2003, p.50)

O filósofo alerta-nos que é precisamente no esforço de memória que ocorre um cruzamento entre a dimensão intelectual e a dimensão afetiva, na medida em que o trabalho de rememorar, de povoar com imagens o que se apresenta inicialmente como um esquema, ou como palavras soltas que significam algo, mas que não conseguimos situar no tempo, em nosso intelecto. Nosso corpo é afetado em forma de inquietude.

Lá em Itaiópolis que dá uns 700 quilômetros, por aí, lá era uma área de bastante madeira, bastante mato nativo e lá nós tivemos muita dificuldade. Porque chegando lá e na impossibilidade de ser assentado por causa da questão da madeira, começamos a enfrentar a influência dos madeireiros, dos pistoleiros etc. Tinha interesse na madeira, então aconteceu uma divisão muito grande, uma divisão interna do acampamento. Entre os companheiros, as pessoas que os madeireiros convenceram para vender a madeira e entre os outros companheiros e as outras pessoas que não queriam mexer na madeira. Então naquele momento foi bastante difícil, nós os dirigentes, as lideranças passaram muitas dificuldades, perseguição (a narrativa aqui é intercalada pela emoção) inclusive... teve companheiro que... teve companheiro que... teria que... pra dormir no seu barraco tinha que 
fazer guarita... Outros companheiros tinham que cuidar, que vigiar, porque corriam riscos de vida. Daí eu lembro dos companheiros, valorosos companheiros que estão com nós até hoje, companheiro André que passou por essas dificuldades, Carlos, a Maria, o Dirceu.

E é precisamente nessa inquietude que intelecto e afecção se cruzam, demonstrando, assim, que há afecção na busca: "Así se cruzan de nuevo la dimensión intelectual y la dimensión afectiva del esfuerzo de rememoración, como en cualquier otra forma del esfuerzo intelectual" (Ricoeur, 2003, p.50).

Situamos esse esforço de lembrar, a evocação, na qual intelecto e afecção se cruzam, também em outro momento da pesquisa de campo. Quando perguntamos a um dos assentados como a História forma politicamente o sujeito Sem Terra, na resposta, surgiu a presença do esforço e da afecção. Observemos:

Parece mentira que há 12 anos passamos necessidades. Lembramos o passado. Aprendeu-se muitas coisas pelo que se vivia. No segundo ano que estávamos aqui compramos o primeiro tratorzinho e ninguém vendia óleo diesel a fiado. Então viemos para o assentamento e lá na roça mesmo fizemos uma assembleia para vender sacas de milho e aí comprar óleo. As mulheres disseram que tudo bem, mas que não podia faltar para a polenta, porque era o que mais se comia. (João, assentado no Conquista da Fronteira)

Nas expressões do assentado podemos observar a sobriedade de quem narra a superação das dificuldades, num esforço para localizar em sua memória o vivido e o sentido em outro tempo, e até o riso, pelo que hoje parece algo inusitado, vender sacas de milho para abastecer um trator, correndo-se o risco de faltar o alimento.

Nesse esforço de memória, em que o lembrado é a matéria do lembrar, Ricoeur nos alerta que há também uma memória do esquecimento, pois, ao nos esforçarmos para lembrar o que esquecemos, correspondemos à finalidade primeira da memória, a de lutar contra o esquecimento. No dever de memória, na compreensão do filósofo, está, portanto, implicado o dever de não esquecer, porque "aprendeu-se muitas coisas pelo que se vivia".

É precisamente nesse paradoxo, em que lembrar implica não esquecer, que Agostinho situa suas reflexões. Sob o título "A memória lembra-se do esquecimento", inicia sua reflexão com a pergunta: "E mesmo quando falo no 
esquecimento e conheço o que pronuncio, como poderia reconhecê-lo, se dele me não lembrasse?” (Agostinho, 1999, p.275). E entre outras perguntas e reflexões indaga: "Que é esquecimento senão a privação da memória? E como é, então, que o esquecimento pode ser objeto da memória se, quando está presente, não me posso recordar?" (Agostinho, 1999, p.275). Prossegue em suas especulações, afirmando que está certo que lembra de seu esquecimento. Com efeito, se lembramos que esquecemos, realmente esquecemos? Como lembramos se esquecemos?

Na compreensão de Ricoeur (2003) está posto o enigma de saber fenomenológico, qual seja: "si no el olvido es sólo impedimento para evocar y para reencontrar el 'tiempo perdido', o si proviene del ineluctable desgaste 'por' el tiempo de las huellas que dejaron en nosotros, en forma de afecciones originarias, los acontecimientos sobrevenidos" (2003, p.51). O não saber expresso pelo autor denota a necessidade implícita à questão formulada, de recorrer à liberação absoluta do esquecimento sobre a qual se destacam as lembranças salvas do esquecimento, e, também, buscar junto às neurociências e as ciências cognitivas esse saber que por ora nos falta. Ao anunciar que "chegando aqui, também no acampamento nós tivemos inúmeras dificuldades, precisaria muito tempo para falar", provavelmente o "muito tempo para falar" denota lembranças, mas também esquecimentos, pois indica que ele fez uma seleção, e que nessas lembranças estavam aquelas que salvou do esquecimento, que necessitou liberar para ser possível salvar algumas lembranças, talvez até como um esforço de memória para narrar o que compreendeu como politicamente pertinente naquele momento, o que não desqualifica o esforço de memória com base em um esquema que ele tenha elaborado.

Ricoeur define outro binômio concernente a uma fenomenologia da memória, qual seja, reflexividade e mundanidade. Parece-nos que esse binômio religará o fenômeno da memória ao mundo, no sentido de termos inferido à memória questões de sua interioridade fenomenal sem, contudo, tomá-la em sua relação mundana.

Uno no se acuerda solo de si, que ve, que siente, que aprende, sino también de las situaciones mundanas en las que se vio, se sintió, se aprendió. Estas situaciones implican el cuerpo propio y el cuerpo de los otros, el espacio en fin, el horizonte del mundo y de los mundos bajo el cual algo aconteció. (Ricoeur, 2003, p.58) 
A reflexividade, como traço da memória interior, é inegável, mas isso não a restringe a uma relação dialética com o mundo, a exterioridade. Relação que não é autorizada pela fenomenologia husserliana, que intenta fazer aparecer às coisas mesmas. Diríamos, assim, que o aporte da lembrança está na mundanidade. Observemos as inúmeras vezes que Ilário se refere aos outros para amparar suas lembranças, conferindo-lhes, assim, um aspecto de veracidade, mas principalmente ligando-a à mundanidade. Ricoeur (2003) se apoiará em Edward Casey (1987), considerando que esse autor contribui para pensarmos a memória feliz a partir de três modos mnemônicos.

O primeiro modo, denominado Reminding, refere-se ao lembrar em que "isto me lembra aquilo". São os indicadores que nos protegem do esquecimento, distribuídos entre os lados da divisão interioridade-exterioridade. As lembranças podem ocorrer de forma quase mecânica na rememoração. Sob o mesmo modo, encontramos também as lembranças em pontos de apoio exteriores para a rememoração, como fotos, postais etc. Esses indicadores nos protegem contra o esquecimento futuro.

Como segundo modo, Casey, conforme Ricoeur, aponta o Reminiscing. Neste modo de lembrar, há mais atividade que no anterior, pois se trata de fazer reviver o passado, evocando-o a vários, em que a ajuda mútua faz memória dos acontecimentos ou de saberes compartilhados, mediante a conversação.

O terceiro modo mnemônico é o Recognizing, em que há um reconhecimento, como a mesma lembrança da impressão primeira buscada como distinta. A lembrança como presença do ausente e enquanto outra que emana do passado distinto, reconhecida como a mesma (Ricoeur, 2003, p.60-61). Essa alteridade em relação ao passado varia entre graus distintos, ou seja, há uma alteridade zero quando há um sentimento máximo de familiaridade, e o contrário quando há um sentimento máximo de estranheza. Entre os dois graus de alteridade, o grau intermediário ocorre quando o sentimento de estranheza e familiaridade é médio. Para Ricoeur (2003):

Este punto medio anuncia, en el plano de la fenomenología de la memoria, la operación crítica por la que el conocimiento historico restituye su objeto al reino del pasado existido, haciendo así de él lo que Michel de Certeau llamaba el "ausente de la historia". (Ricoeur, 2003, p.61) 
No reconhecimento se situaria o que o filósofo nomeia como o pequeno milagre, o recobrimento do presente pela alteridade do existido, em que a lembrança é representação, e o passado reconhecido pode também figurar como passado percebido. Aponta para o fato de o reconhecimento do passado ser tratado assim sob a fenomenologia da memória e da percepção (Ricoeur, 2003, p.62).

A rememoração como reconhecimento implica outros elementos exteriores em que se apoiam as lembranças, quais sejam, os lugares, o espaço. Ao lembrar a partir de aportes como isso me lembra aquilo, ocorre uma associação entre lugar e memória, o que conheceremos como lugares de memória, originando uma problemática referente ao fenômeno da datação e localização, evidenciando a questão de como uma fenomenologia da datação e da localização poderia se constituir sem um aporte do conhecimento objetivo. Assim, a fenomenologia pura se inviabilizaria?

Ricoeur postula que esse ponto, em que nos encontramos diante da necessidade de datar as comemorações como recurso ao não esquecimento, coloca-nos diante da afirmação de que o esquecimento opera no ponto de união do tempo e do movimento físico, em que o tempo consome e desfaz. Finalização indecisa realizada por Ricoeur em sua fenomenologia da memória, que é aqui interrompida, mais que concluída, como afirmado por ele mesmo: "Con esta observación de indecisión interrumpo, más que concluyo, este esbozo de la fenomenología de la memoria” (Ricoeur, 2003, p.67).

Essa interrupção de uma fenomenologia da memória, identificada ao encontrar-se com uma aporia que não mais a sustenta, no sentido de que ela necessita de um aporte físico, também nos permite um deslocamento da problemática, cujo objeto ainda não foi abordado, mais precisamente a da lembrança e a da imagem. Até este ponto da análise, refletimos sobre as operações da memória, seu funcionamento, em que a lembrança constituía o foco, mas no que se constitui essa lembrança nos permitirá uma aproximação da temática relativa à imaginação e à lembrança. O que é real e irreal no lembrado?

Ricoeur (2003) adota a perspectiva de Bergson, ao admitir que a lembrança-pura se situa em dois polos, o da memória que vê de novo, e o da memória que repete, havendo entre as duas um nível intermediário, precisamente o da lembrança-imagem. Contudo, a problemática da imaginação se evidencia, 
considerando-se que essa operação intermediária em que a lembrança-imagem vista por diante dos olhos é virtual. Adverte-nos que imaginar não é lembrar. Isso implica admitirmos que o objeto lembrado com o auxílio da imagem não é o objeto apreendido como real. A problemática que se coloca, então, é a da fidelidade da memória, que se constitui em uma reivindicação, a da verdade da memória, considerando-se que há um trabalho de memória ao passar da lembrança-pura para a lembrança-imagem.

Com efeito, as denúncias de abusos de memória e de seu correlato, o esquecimento, ancoram-se nessa reivindicação de verdade da memória. Vivenciamos, em nossa época, uma enxurrada de reivindicações pelas memórias negadas, pelo reconhecimento das memórias de diferentes grupos sociais que reivindicam o reconhecimento de suas memórias e de sua história. Huyssen (2000, p.9) nos alerta que "um dos fenômenos culturais e políticos mais surpreendentes dos anos recentes é a emergência da memória como uma das preocupações culturais e políticas centrais das sociedades ocidentais”.

Diversos outros autores, estudiosos de diferentes áreas do conhecimento, abordam a memória e acompanham Huyssen nessa observação de que, na atualidade, está ocorrendo uma "revalorização da memória, tanto na esfera individual como nas práticas sociais ou mesmo no interior da historiografia, o acúmulo de falas memória, sua operacionalização cada vez mais eficaz, o direito e o dever de memória reivindicados por grupos sociais e políticos" (Seixas, 2001, p.38). Reivindicações que buscam reparar um esquecimento, uma humilhação sofrida, pois "o dever de memória concerne, em primeiro lugar, à memória dos fatos, das provas e sofrimentos suportados, que são exortados a não serem esquecidos" (Ansart, 2001, p.30).

Na memória exercida, podemos observar os usos e abusos da memória, em sua dimensão pragmática, considerando-se que "acordarse es no solo acoger, recibir una imagen del pasado; es también buscarla, 'hacer' algo" (Ricoeur, 2003, p.81). Exercer a memória significa então fazer uso dela, porém há uma diferença entre memorizar e rememorar. A rememoração implica trazer à consciência algo que teve lugar no passado, antes do presente, como evocação simples ou reconhecimento que conclui o processo de recordação. Ao questionarmos as crianças sobre a história do assentamento ouvimos estas narrativas: 


\section{Me conta a história do assentamento?}

Eu sabia que eles vinham duma terra onde tinha um riacho e uma ponte. E aquela terra é difícil de plantar e difícil de produzir as comidas. Daí eles decidiram e foram lá numa fazenda, daí de lá eles saíram voltaram lá de novo. Daí eles tavam lá veio a polícia pam, colocou fogo... e as mulher desceram do caminhão e apagaram. Daí eles decidiram apagar o fogo, daí eles tavam numa parte do caminho daí a polícia atacou, tocaram de voltar. Daí um dia as pessoas vieram de kombi daí tinha policial na entrada, daí eles voltaram. Daí eles decidiram então de vim. Daí eles vieram com a kombi outra vez, daí expulsou o fazendeiro de lá, daí eles vieram aqui. Era uma noite muito escura não dava pra ver nada. Daí no outro dia o sol saiu daí eles puderam ver. (Mateus - filho de assentados no Conquista na Fronteira $-4^{\text {a }}$ série)

\section{O que você sabe da história do Assentamento?}

Eu sei que as pessoas que moram no assentamento eles tiveram que ir no acampamento lá em... acho que foi em Abelardo Luz, e um dia frio né, de muita cerração eles puderam vir pra cá e eles tavam muito alegres e querendo ver as terras, só que, as terras, as nossas e daí eles foram lá numa casa que tem, pra baixo que era do fazendeiro, que agora nem mora mais aqui, e eles ficaram lá morando por um tempo, daí veio chegando gente aqui, eles vieram se organizando e daí conseguiram fazer o assentamento. (José - filho de assentados no Conquista na Fronteira $-4^{\text {a }}$ série)

As crianças narram essa história, mencionando até mesmo as necessidades vivenciadas no acampamento. Contudo, não as viveram, o que sabemos pela sua idade, pela história do assentamento e pelas reticências em suas narrativas. Nessa reflexão que Ricoeur realiza, e que acompanhamos, questionamo-nos em relação à busca que essas crianças fazem. Que imagens elas buscam se não as viveram? E, contudo, elas narram. Tratar-se-ia então de memorização, ao invés de rememoração?

Memorizar aproxima-se da memória-hábito, é um processo de aprendizagem pelo exercício, implica a relação entre um mestre e um aprendiz. Nessa relação há o ensinado, e nisso reside um aspecto político significativo para nossa temática a ser considerado. Em educação fez-se uso da memória como forma de transmitir às novas gerações aquilo que a sociedade considera como patrimônio cultural. Essa transmissão não é aleatória. Ela está imbuída de uma autoridade enunciativa, porque seu objeto constitui-se como patrimônio 
construído por uma determinada sociedade e que ela julga deva ser transmitido e preservado, inclusive de memória. Assim, o memorizado é aprendido, e dele pode-se fazer uso tanto no exercício de uma profissão como nas diferentes artes como a dança, o teatro e outras, em que a memória é um recurso fundamental e não implica apenas repetição, mas também criação.

Os diferentes usos que fazemos da memória, implicados aí os abusos, são anunciados e discutidos por Ricoeur (2003) como La memoria impedida, La memoria manipulada e La memoria obligada.

A memória impedida pode ser compreendida como a memória ferida, doente, e é abordada por Ricoeur no nível patológico, como a memória que necessita ser curada. Relativa ao indivíduo, nas análises de Freud, mas não somente a ele, visto que ela também pode ser compreendida como um estado de memória coletiva, a memória impedida refere-se à situação em que o indivíduo passa ao ato, ou seja, reproduz a ação sem, contudo, lembrar-se, sem saber que repete. São situações em que um indivíduo repete ações sem saber que as repete. Logo, não lembra e, assim, não localiza a situação que o impele à repetição. Para superar essa compulsão à repetição há um trabalho a ser realizado pelo indivíduo, que é o trabalho de rememoração em busca de uma relação verdadeira com o passado. Está implicada nesse trabalho a resistência, e evidencia-se o vínculo entre a compulsão de repetição e a resistência.

Um outro estado em que a memória é compreendida como doente relaciona-se ao duelo e à melancolia, que Ricoeur (2003, p.99) aponta como o título de um ensaio de Freud, pelo qual mostra que o duelo é o trabalho que permite descobrir os enigmas da melancolia. A melancolia é expressa pela diminuição do sentimento de si, e no trabalho de duelo não há diminuição do sentimento de si. Esse trabalho de duelo segundo Ricoeur (2003), com base em Freud, significa que o objeto amado deixou de existir. Pessoa amada, pátria, ideal etc., e toda a libido está ordenada a renunciar ao vínculo que a une a esse objeto, produzindo uma revolta contra isso, pois, psiquicamente, o objeto continua a existir, e a libido continua ligada ao objeto perdido. Aí temos uma sobreatividade das lembranças do objeto amado, e são essas que necessitam ser liquidadas. Por isso o trabalho de duelo (Ricoeur, 2003, p.100-101).

Apesar de doloroso, o trabalho de duelo, quando encerrado, libera o indivíduo, assim como o trabalho de rememoração afasta a compulsão por repetição, diferentemente da melancolia em que o indivíduo cai sobre sua 
própria desvalorização, autoacusando-se. Isso promove a transformação da discórdia com o outro em dilaceração de si. Contudo, ela também pode desaparecer depois de um tempo, sem deixar grandes transformações (Ricoeur, 2003, p.102). Para não deixar a melancolia ao sabor do tempo, Ricoeur (2003) postula a sublimação da tristeza pela poesia, transformando-a em alegria, como recompensa pela renúncia ao objeto perdido.

Transpor as categorias patológicas de Freud para a memória coletiva é o desafio a que Ricoeur (2003) se propõe e que nos interessa particularmente. Para o filósofo, o outro da situação individual pode ser concebido como o outro social ou, ainda, o outro da situação histórica, principalmente quando nos propomos a refletir sobre a produção de um passado comum por um grupo social que necessita uma memória comum como referência.

Es la constitución bipolar de la identidad personal y de la identidad comunitaria la que justifica, en último término, la extensión del análisis freudiano del duelo al traumatismo de la identidad colectiva. Se puede hablar, no sólo en un sentido analógico sino también en los términos de un análisis directo, de traumatismo de la identidad comunitaria la que justifica, en último término, la extensión del análisis freudiano del duelo al traumatismo de la identidad colectiva. (Ricoeur, 2003, p.108)

Podemos situar as perdas coletivas de um grupo social, de uma comunidade, aquelas referentes à perda de território, de autonomia política, enfim, perdas históricas, que resultam em uma memória coletiva ferida.

A memória manipulada por aqueles que detêm o poder pode nos levar a experienciar os abusos de memória, em que ela é erigida como critério de identidade pessoal ou coletiva, como o centro da problemática na mobilização da memória.

As manipulações de memórias ocorrem diante de um fator inquietante e multiforme que, segundo Ricoeur (2003), se intercala entre a reivindicação de identidade e as expressões públicas de memória, a ideologia. Caracteriza-a como um processo opaco, porque permanece oculto, mascarado. Pela complexidade do fenômeno, o autor identifica três níveis operativos que são exercidos sobre a compreensão do mundo pelo homem. São efeitos produzidos de cima para baixo, quais sejam de distorção da realidade, de legitimação do sistema de poder e de integração do mundo comum por meio de sistemas simbólicos imanentes à ação (Ricoeur, 2003, p.113). 
No nível mais profundo, o fenômeno ideológico parece constituir uma estrutura insuperável da ação, na medida em que a mediação simbólica cria a diferença entre as motivações da ação humana e as estruturas hereditárias dos comportamentos programados geneticamente.

Agindo pelas estruturas simbólicas, a ideologia tende a legitimar as estruturas de poder estabelecidas, atuando em diferentes instâncias, como na memória constituinte de uma identidade.

En el plano más profundo, el de las mediaciones simbólicas de la acción, la memoria es incorporada a la constitución de la identidad a través de la función narrativa. Y como la configuración de la trama de los personajes del relato se realiza ao mismo tiempo que la de la historia narrada, la configuración narrativa contribuye a modelar la identidad de los protagonistas de la acción al mismo tiempo que los contornos de la propia acción. (Ricoeur, 2003, p.116)

Compreende Ricoeur (2003) que essa memória constituinte de uma identidade, viabilizada pela função narrativa, está “autorizada” por uma história, frequentemente a oficial, que é aprendida e celebrada publicamente.

Essa memória é aprendida como a memória comum pertencente a um grupo, que, através de narrativas históricas, valida-a como uma memória verdadeira, que o identifica como grupo. Memorização forçada, que se ancora na rememoração possibilitada pela história e celebrada por esse grupo. Assim, memorização, rememoração e comemoração compõem uma tríade que se revela em uma posição incontestável para os membros desse grupo social. Então, as narrativas reproduzidas pelas crianças seriam o resultado de uma memória produzida, porque elas se sentem pertencentes a esse grupo e, possivelmente, ao reproduzir as memórias do grupo, como suas memórias, porque assim as sentem, as imagens evocadas refiram-se a sua escuta dessas narrativas, mas, principalmente, às vivências simbólicas de memória, em que os símbolos são os elementos fundadores dessas memórias que, neste caso, referem-se à memória das vítimas, que reclamam o seu direito à memória. Acompanhemos um dos momentos que vivenciamos no Assentamento:

É o dia 8 de outubro ... No assentamento, todo dia 8 de outubro é rememorado e comemorado como o "Dia do trabalho voluntário", uma celebração à morte de Che Guevara, ocorrida no dia 9 de outubro do ano de 1967, na Bolívia ... No salão 
comunitário, na parede lateral, branca, uma pintura da face de Che Guevara ocupa todo o espaço ... São adultos e crianças de todas as idades, desde aqueles que nem sequer aprenderam a caminhar, até aqueles cujas marcas do tempo orgulham sua experiência de vida. $\mathrm{O}$ tom é solene... Uma mulher, em meio às pessoas, pergunta em voz alta: Quem foi? Quem foi Ernesto Che Guevara de La Sierna? Todos se erguem e, acompanhados pelo som do violão, cantam a música "Sonhar grande". Enquanto cantam, um homem entra no recinto portando uma imagem de Che Guevara, estampada sob o mapa da América Latina, e se posta à frente, segurando a imagem de mais ou menos $1 \mathrm{~m}$ de altura por $80 \mathrm{~cm}$ de largura. Após o canto, as pessoas se sentam, e a mulher que antes perguntava, agora, com a voz pausada, caminhando suave e lentamente, sempre se dirigindo aos presentes, narra a cronologia da vida de Che Guevara, do nascimento à vitória do Movimento Revolucionário em Cuba, até sua morte na Bolívia. Em seguida, a mística prossegue com a participação de jovens, mulheres e homens que, ao questionamento da narradora sobre o pensamento de Che em relação aos militantes, aos jovens, às mulheres, ao trabalho e ao trabalho voluntário, erguem-se, cada qual a seu tempo, e se dirigem aos presentes, fazendo a leitura de excertos escritos por Che Guevara. O intuito é orientar as ações de militantes, jovens, homens e mulheres na realização da revolução socialista, prescrevendo o papel de cada um na referida transformação social. Todos se erguem e cantam a música "Se não houver amanhâ", enquanto o homem afixa a imagem de Che na parede ... Em seguida, um vídeo sobre a vida de Che Guevara é exibido aos presentes, aplaudido com entusiasmo ao ser finalizado. Assim que encerrados os aplausos, todos os presentes cantam o hino do Movimento Sem Terra e finalizam a celebração, bradando com o pulso esquerdo erguido: Che, Zumbi, Antonio Conselheiro, na luta por justiça nós somos companheiros! Che, Zumbi, Antonio Conselheiro, na luta por justiça nós somos companheiros! Che, Zumbi, Antonio Conselheiro, na luta por justiça nos somos companheiros! (Transcrição da fita de vídeo e diário de campo, 8 out. 2005)

No processo em que o passado é convocado para sedimentar uma memória por meio de narrativas históricas que permitem a esse grupo re-ligar-se, estar-junto e pertencer, a prática da celebração revela-se como uma prática social que constitui um patrimônio do grupo.

Como indica Balandier (1999), as memórias coletivas têm uma impressionante resistência aos golpes da História, pois em momentos difíceis em que os totalitarismos se impõem, recolhem-se e, posteriormente, ressurgem com força: 
em situações em que o laço social mostra-se enfraquecido, a relação com o passado faz as vezes de remédio para essa carência; é instada a re-ligar por meio de uma continuidade valorizada, de dar um patrimônio para repartir, mesmo quando este é gerador de artifícios de interpretação, de disputas e confrontos. (Balandier, 1999, p.51)

Assim, os despossuídos da terra, os que ficaram à margem, os sem memória, para sobreviver como coletividade necessitam de uma memória comum para re-ligar. Para sedimentar uma memória como a sua memória há um trabalho de produção dessa memória que se realiza como prática social e dessa forma constitui seu patrimônio. Para além da terra, os Sem Terra buscam na História a sua memória, uma memória dos trabalhadores.

Nessa necessidade de lembrar, de possuir uma memória comum, Ricoeur (2003) adverte-nos para o perigo de que esse convite dirigido à memória entre em choque com a história. A preocupação do autor está em que a memória seja tomada em detrimento da história, não consistindo nisso o objetivo da discussão, tanto quanto não se trata de reduzir a memória a um simples objeto da história. Trata-se de conceber a memória com uma função matricial da história.

Contudo, o dever de memória, situado entre o sentimento de débito e de reivindicação de memória, remete-nos para a necessidade de justiça, que pode, contudo, resultar em excessos de memória no plano da manipulação ideológica, mas também pode significar um valor exemplar, transformando-a em projeto:

Es la justicia la que, al extraer de los recuerdos traumatizantes su valor ejemplar, transforma la memoria en proyecto; y es este mismo proyecto de justicia el que da al deber de memoria la forma del futuro y del imperativo ... Lo que hay que examinar es la relación del deber de memoria con la idea de justicia. (Ricoeur, 2003, p.120-121)

A relação entre o dever de memória e a ideia de justiça comporta três elementos. Primeiramente, o dever de memória se constitui em relação ao outro, lembra ao outro. Em segundo lugar, o dever de memória nos remete à dívida que temos com o outro, que implica submeter essa herança a inventário. E, por último, em relação aos que estamos endividados, prevalecerá a prioridade moral das vítimas. 
Essas questões, que consideram o dever de memória como a necessidade de fazer justiça ao outro, diverso de nós, remetem-nos a considerar até que ponto esse dever de memória pode se converter em abuso de memória. Ricoeur (2003, p.122), ao colocar essa questão, indica-nos que "el deber de memoria hesita continuamente entre uso y abuso porque su proclamación permanece cautiva del síndrome de obesión”.

Assim, a memória manipulada, não pela ideologia, mas pelo inconsciente, pela "palavra muda" das vítimas, que transformam o uso em abuso, que pode inclusive manifestar-se na obsessão comemorativa.

A obsessão comemorativa da memória das vítimas pode produzir uma inversão do histórico em comemorativo, em que memória e história tornam-se um só, uma identificação por filiação, característica que excede os limites do bom uso da memória, sob o signo da necessidade de justiça.

Nesse sentido, ao finalizarmos essa reflexão, a questão apontada no título necessita resposta. Compreendemos que o grupo social pesquisado desenvolve uma prática social em que história e memória se recobrem.

Contudo, há que se considerar que a produção de uma memória dos trabalhadores do campo irrompe diante dos silenciamentos das histórias dos que estavam à margem. Trata-se de produzir uma história que constitua um patrimônio que possa ser compartilhado com as novas gerações. Com efeito, há um investimento do grupo na produção de uma memória patrimônio que se efetiva num movimento em que a história dos trabalhadores alimenta sua prática social.

\section{REFERÊNCIAS}

AGOSTINHO, S. Confissões Livro X: O encontro de Deus. Trad. J. Oliveira Santos, S.J., e A. Ambrósio de Pina, S.J. São Paulo: Nova Cultural, 1999. p.257-307. (Os pensadores).

ANSART, P. História e memória dos ressentimentos. In: BRESCIANI, S.; NAXARA, M. (Org.) Memória e (res)sentimento: indagações sobre uma questão sensível. Campinas, SP: Ed. Unicamp, 2001. p.15-36.

BALANDIER, G. O dédalo: para finalizar o século XX. Trad. Suzana Martins. Rio de Janeiro: Bertrand Brasil, 1999.

CERTEAU, M. A invenção do cotidiano. 9.ed. Trad. Ephraim Ferreira Alves. Petrópolis, RJ: Vozes, 1994. 
CONNERTON, P. Como as sociedades recordam. Trad. Maria Manuela Rocha. 2.ed. Oeiras, Portugal: Celta, 1999.

HUYSSEN, A. Seduzidos pela memória: arquitetura, monumentos, mídia. Rio de Janeiro: Aeroplano, 2000.

HUSSERL, E. Fenomenologia de la consciencia del tiempo inmanente. Trad. Ivonne Picard. Buenos Aires: Editorial Nova, 1959.

POLLACK, M. Memória e identidade social. Estudos Históricos, Rio de Janeiro, v.5, n.10, p.200-212, 1992.

RICOEUR, P. La memoria, la historia, el olvido. Madrid: Trotta, 2003.

SEIXAS, J. A. de. Percursos de memórias em terras de História: problemáticas atuais. In: BRESCIANI, S.; NAXARA, M. Memória e (res)sentimento: indagações sobre uma questão sensível. Campinas, SP: Ed. Unicamp, 2001.

\section{NOTAS}

1 "Memórias poderosas" é uma expressão utilizada por Georges Balandier (1999) para designar as memórias que resistem ao esquecimento e ressurgem vigorosamente em tempos de reivindicações do direito à memória.

${ }^{2}$ Em 24 de junho de 1988, no município de Dionísio Cerqueira, Santa Catarina, foram assentadas 35 famílias oriundas do Movimento dos Trabalhadores Sem Terra, as quais haviam passado por um processo de 3 anos de discussão política sobre a questão da terra e a reforma agrária. Outras 25 famílias foram indicadas pela municipalidade. Os critérios para escolha das 25 famílias, basicamente dois, foram indicados pelas comunidades locais: ou famílias muito pobres com muitos filhos, ou aquelas famílias que não se "enquadravam" nos padrões das comunidades locais. Portanto, a diversidade de origem das 70 famílias assentadas não inviabilizou a constituição de uma memória do grupo que hoje constitui o Assentamento Conquista na Fronteira (Relato da Comissão de Educação do Assentamento "Conquista na Fronteira" à pesquisadora em 14 jun. 2005).

${ }^{3}$ Como um dos elementos que colaboram para essa oficialização dentro do Movimento Sem Terra encontramos o Calendário Histórico dos Trabalhadores.

Artigo recebido em 24 de setembro de 2014. Aprovado em 23 de outubro de 2014. 